\title{
Koneksi Matematis Siswa dalam Menyelesaikan Masalah Tidak Lengkap dalam Diskusi Kelompok
}

\author{
Nadia Nurudini ${ }^{1}$, Susiswo $^{1}$, Sisworo ${ }^{1}$ \\ ${ }^{1}$ Pendidikan Matematika-Universitas Negeri Malang
}

\begin{tabular}{l}
\hline \hline INFO ARTIKEL \\
\hline Riwayat Artikel: \\
Diterima: 14-05-2019 \\
Disetujui: 17-10-2019 \\
\hline
\end{tabular}

\section{Kata kunci:}

mathematical connection; incomplete problem; group discussion; koneksi matematika; masalah tidak lengkap; diskusi kelompok

\begin{abstract}
The purpose of this study is to describe students' mathematical connection ability on cube material in solving incomplete problems in group discussion. The sample in this study were 3 groups that has high, medium, and low mathematical abilities. The results of this study was found that the students with high ability were able to understand all mathematical connection indicators, which were finding the connection between mathematical topics, finding the connection of mathematics to other knowledges, and finding the connection of mathematics to dayly life. The students with medium ability were able to understand the first and second indicators. The students with low ability were only able to understand one indicator which was finding the connection between mathematical topics.
\end{abstract}

ABSTRAK

\begin{abstract}
Abstrak: Tujuan dari penelitian ini adalah untuk mendeskripsikan kemampuan koneksi matematis siswa pada materi bangun ruang kubus dalam menyelesaikan masalah tidak lengkap dalam diskusi kelompok. Sampel dalam penelitian ini diambil tiga kelompok siswa yang memiliki kemampuan matematis tinggi, sedang, dan rendah. Dari hasil penelitian diperoleh bahwa siswa berkemampuan tinggi dapat menguasai ketiga indikator kemampuan koneksi matematis, yaitu koneksi matematis antar topik matematika, koneksi matematis dengan mata pelajaran lain, dan koneksi matematis dengan kehidupan sehari-hari. Siswa berkemampuan sedang dapat menguasai indikator I dan II. Siswa berkemampuan rendah hanya menguasai satu indicator, yaitu koneksi antar topik matematika.
\end{abstract}

\author{
Alamat Korespondensi: \\ Nadia Nurudini \\ Pendidikan Matematika \\ Universitas Negeri Malang \\ Jalan Semarang 5 Malang \\ E-mail: nadia.nurudini.1703118@students.um.ac.id
}

Dalam kehidupan manusia, matematika mempunyai peranan yang sangat penting (Sapto, Suyitno, \& Susilo, 2015) dikarenakan matematika membentuk pola pikir manusia dengan logis, sistematis, dan kritis. Matematika tidak hanya digunakan dalam aktifitas kehidupan sehari-hari, tetapi juga digunakan untuk menunjang berkembangnya ilmu pengetahuan yang lain, seperti ilmu fisika, ekonomi, dan lainnya. Dalam hal ini, Fathani (2009) menyatakan bahwa salah satu kegunaan matematika adalah sebagai ilmu pikir sehingga matematika sangat penting bagi berlangsungnya kehidupan manusia. Matematika terdiri dari bermacam-macam topik yang mana antara topik satu dengan lainnya saling berkaitan. Keterkaitan tersebut terdiri dari keterkaitan antar topik dalam matematika, keterkaitan matematika dengan ilmu lain, dan dengan kehidupan sehari-hari. Menurut Rohendi (2012) pemahaman siswa dalam menghubungkan ide-ide terhadap kemampuan memverifikasi dan merumuskan dugaan deduktif antar topik dalam matematika merupakan definisi dari koneksi matematis.

Kemampuan koneksi matematis adalah salah satu kemampuan yang disarankan oleh NCTM. Menurut NCTM (2000), melalui studi matematika keterampilan matematika yang penting untuk dikembangkan, meliputi (1) problem solving, (2) reasoning and proof, (3) communication, (4) connection, and (5) representation. Koneksi matematis merupakan kegiatan menghubungkan materi yang telah dipelajari dengan materi yang baru, sejalan dengan hal ini (Haji, Abdullah, Maizora, \& Yumiati, 2017) menyatakan bahwa kemampuan koneksi matematis adalah kemampuan siswa dalam menghubungkan berbagai topik yang berhubungan dengan matematika, tidak hanya topik-topik dalam matematika, tetapi juga antara matematika dengan hal-hal di luar matematika. Seperti contoh menghubungkan konsep aljabar dengan konsep geometri yang dihubungkan dengan ilmu lain dan kehidupan sehari-hari.

Koneksi matematis menghubungkan materi yang mana tidak hanya materi dalam matematika saja, tetapi juga di luar matematika. NCTM (2000) membagi koneksi matematis menjadi tiga aspek, yaitu koneksi matematis antara topik matematika, koneksi matematis dengan ilmu lain, dan koneksi matematis dengan kehidupan sehari-hari. Sependapat dengan itu, menurut Ainurrizqiyah, Mulyono, \& Sutarto (2015), koneksi matematis merupakan kegiatan mengenal ide-ide dalam matematika, memahami apa itu koneksi ide, dan mengenal matematika baik dalam konteks antar matematika maupun dengan konteks di luar 
matematika. Berdasarkan uraian di atas, penelitian ini menfokuskan pada tiga indikator koneksi matematis yang dilakukan siswa dalam menyelesaikan soal materi bangun ruang sisi datar khususnya kubus dan balok, yaitu (1) aspek koneksi antar topik matematika, (2) aspek koneksi dengan mata pelajaran lain, dan (3) aspek koneksi dengan kehidupan sehari-hari.

Menurut McGregor (2014) soal-soal yang tidak terstruktur dalam matematika umumnya dianggap bersifat terbuka, terdapat 'kekacauan' dalam pertanyaannya. Pertanyaan 'kekacauan' inilah yang menunjukkan ketidakjelasan dalam menjawab soal. Dalam Suatu keadaan nanti nya akan menjadi masalah jika siswa menghadapi ketidaknyamanan dalam menyelesaikan masalah matematika, dan tidak tahu bagaimana cara mengatasinya. Dalam hal inilah siswa menyadari bahwa yang mereka hadapi bukan hanya latihan matematika, melainkan merupakan masalah matematis berupa masalah tidak lengkap.

Dalam menyelesaikan masalah tidak lengkap yang dialami siswa dapat dikategorikan sebagai ill-structured problem. Menurut Abdillah \& Mastuti (2018) ill-structured problem adalah jenis suatu masalah yang dihadapi siswa dalam kejadian dikehidupan sehari-hari, tentang aspek matematika, melibatkan unsur-unsur yang belum diketahui sehingga mengharuskan siswa untuk mengekspresikan pendapatnya masing-masing. Aziziy, Sulhadi, \& Hartono (2015) juga berpendapat bahwa untuk menyelesaikan masalah ill-structured problems melibatkan siswa yang aktif dalam proses pembelajaran sehingga menjadikan mereka pelajar yang mandiri. Sejalan dengan hal itu, menurut Redhana, Sudiatmika, \& Artawan (2009) dalam memecahkan masalah ill-structured problem akan membentuk kebiasaan berpikir siswa dimana sangat diperlukan untuk menghadapi kehidupan.

Dalam proses pembelajaran pemilihan metode merupakan hal yang sangat penting, sehingga diperlukan metode yang melibatkan keaktifan siswa. Untuk mencapai tujuan yang diinginkan agar dalam proses belajar mengajar dapat efektif yaitu menggunakan metode diskusi kelompok. Berikut disajikan dokumentasi diskusi kelompok siswa (Gambar 1).

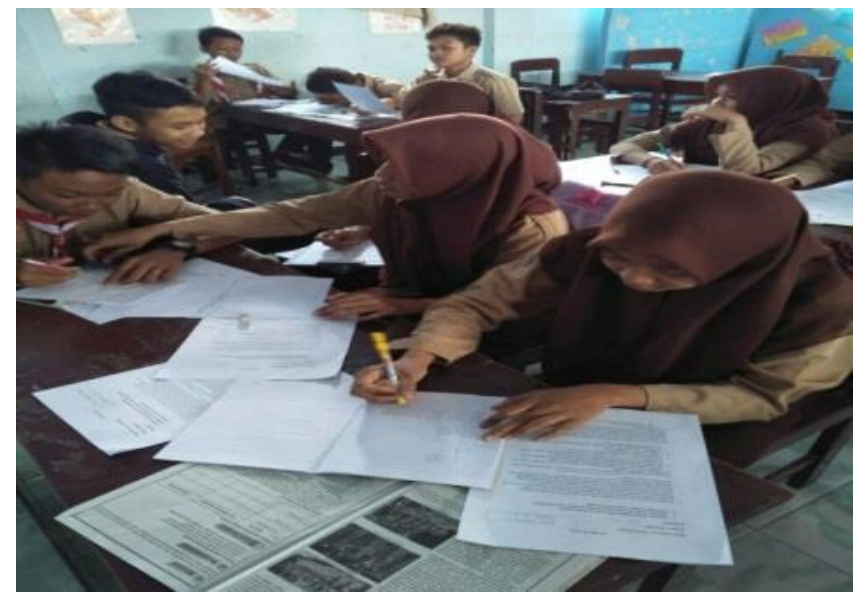

Gambar 1. Diskusi Kelompok Siswa

Menurut Pono \& Lutfi (2012) diskusi kelompok adalah suatu kegiatan dimana para siswa saling bertukar pikiran, informasi, dan pendapat dalam memecahkan masalah. Sehingga dengan metode diskusi kelompok ini, siswa akan lebih berkembang pemikirannya, dan siswa akan lebih leluasa untuk berinteraksi dengan teman sebayanya sehingga semangat untuk belajar meningkat. Diskusi kelompok dapat menumbuhkan keberanian siswa dalam mengemukakan pendapatnya, dapat saling belajar, saling membantu dan dapat menumbuhkan kerjasama baik antar kelompok, maupun dengan kelompok lainnya (Vinsensia, 2016). Penerapan diskusi kelompok dalam pembelajaran dapat meningkatkan aktivitas belajar siswa baik aktivitas mental, fisik dan emosionalnya (Hasanah, Abdussamad, \& Rosnita, 2013). Sejalan dengan hal itu, Adamura (2017) berpendapat bahwa dengan pembelajaran berbasis diskusi kelompok siswa dapat melatih siswa untuk membangun sendiri materi yang dipelajari kemudian mendiskusikannya secara klasikal di dalam kelas.

\section{METODE}

Penelitian ini bertujuan untuk mendeskripsikan kemampuan koneksi matematis dalam menyelesaikan soal tidak lengkap dalam diskusi kelompok. Pendekatan dalam penelitian ini adalah pendekatan kualitatif dan jenis penelitian ini adalah penelitian deskriptif. Data pada penelitian ini adalah kemampuan koneksi matematis. Sumber data dalam penelitian ini adalah siswa kelas VIII MTs Sultan Agung Kalipare yang berjumlah 12 siswa yang terbagi dalam tiga kelompok dan masing-masing kelompok terdri dari empat orang sesuai dengan kemampuan matematis tinggi, sedang, dan rendah.

Pengumpulan data menggunakan tes, observasi, dan metode wawancara. Dengan menggunakan tiga koneksi kemampuan koneksi matematis, yaitu koneksi antar topik dalam matematika, koneksi matematis dengan ilmu lain, dan koneksi matematis dengan kehidupan sehari-hari. Tes kemampuan koneksi matematis diberikan setelah mempelajari bangun ruang sisi datar khususnya kubus dan balok dan hasilnya dianalisis untuk melihat kemampuan koneksi matematis. Instrumen observasi dan 
wawancara dikembangkan untuk menemukan lebih banyak penyebab lemahnya kemampuan koneksi matematis. Observasi dan Wawancara diadakan setelah selesainya menganalisis soal tes koneksi matematis. Analisis data dilakukan melalui teknik kualitatif-deskriptif. Menurut Saminanto (2015) kategori kemampuan koneksi matematika dibagi menjadi tiga level, yaitu tingkat rendah, sedang, dan tinggi terdapat pada tabel 1.

Tabel 1. Kategori Kemampuan Koneksi Matematis

\begin{tabular}{ll}
\hline \multicolumn{1}{c}{ Klasifikasi } & Kemampuan Koneksi Matematis \\
\hline $\boldsymbol{X}<\mathbf{5 5} \%$ & Rendah \\
$\mathbf{5 5} \% \leq \boldsymbol{X}<\mathbf{5 5} \%$ & Sedang \\
$\mathbf{7 5} \% \leq \boldsymbol{X}$ & Tinggi \\
\hline
\end{tabular}

Selanjutnya, data kualitatif dikumpulkan melalui observasi dan wawancara yang akan digunakan untuk melihat koneksi matematika. Wawancara pada penelitian ini digunakan untuk melihat kesalahan dalam melakukan tes kemampuan koneksi matematika.

\section{HASIL}

Deskripsi tentang hasil kerja siswa dan dan hasil wawancara terhadap soal koneksi matematis siswa yang diberikan kepada 12 siswa kelas VIII MTs. Sultan Agung Kalipare dengan jumlah soal sebanyak tiga butir soal. Analisis dilakukan kepada setiap langkah pada proses jawaban siswa disesuaikan dengan tiga indikator kemampuan koneksi matematis siswa, dapat dilihat pada penjelasan di bawah ini.

\section{Deskripsi Siswa dengan Kemampuan Matematis Tinggi}

Berdasarkan jawaban kelompok diskusi yang termasuk dalam kategori siswa yang memiliki kemampuan matematis tinggi, dapat diperoleh kesimpulan bahwa pada indikator koneksi matematis antar topik pada materi luas permukaan bangun ruang, yaitu satu pertanyaan masalah tidak lengkap yang dihubungkan dengan koneksi matematis. Soal untuk mengukur indikator nomor 1 adalah soal nomor 1, berikut jawaban siswa:

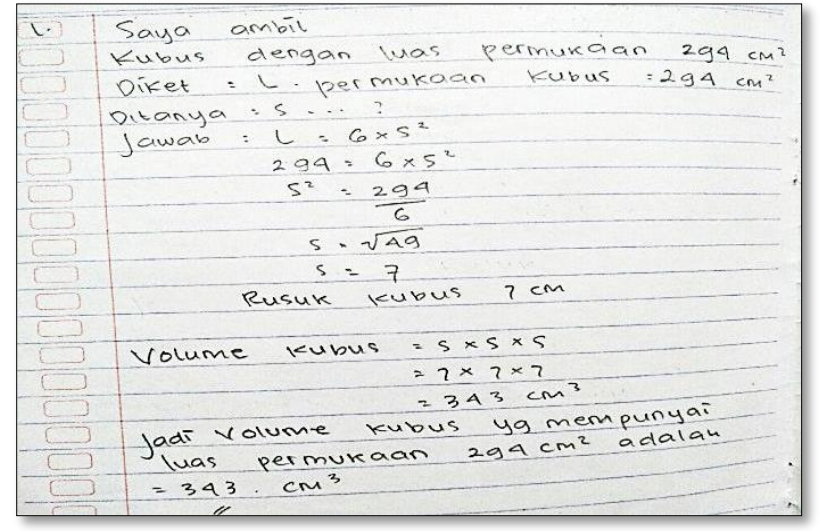

Gambar 2. Hasil Jawaban Kelompok Siswa

Gambar 1 merupakan jawaban soal untuk mengukur indikator koneksi matematis pada aspek koneksi antar topik matematika. Berdasarkan hasil jawaban kelompok, siswa sudah berhasil menambahkan informasi dalam soal tidak lengkap, dan siswa dapat memahami hubungan antara luas permukaan kubus dengan volume kubus. Berikut petikan wawancara dengan salah satu siswa pada kategori kelompok berkemampuan tinggi. Berikut wawancara RA (Anggota salah satu kelompok) pada soal nomor 1 .

P : Bisakah kelompok anda menambah informasi untuk soal tidak lengkap tersebut?

RA : Bisa bu, pada awalnya kelompok kami mendiskusikan kira-kira bangun apa yang cocok dengan luas permukaan bangun yang diketahui dalam soal.

$\mathrm{P} \quad$ : Bisakah kelompok anda menguhubungkan luas permukaan bangun tersebut dengan

Volume bangun ruang?

RA : Bisa bu

$\mathrm{P} \quad$ : Langkah apa yang anda ambil selanjutnya?

RA : tentukan dulu luas permukaan kubus $L=6 s^{2} \leftrightarrow 294=6 \mathrm{~s}^{2} \leftrightarrow \mathrm{s}^{2}=49 \leftrightarrow \mathrm{s}=7 \mathrm{~cm}$

P : Setelah itu bagaimana?

RA : Mencari volume kubus dengan memasukkan nilai sisinya 


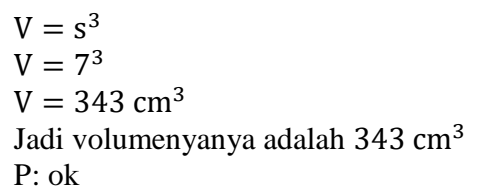

Dari petikan wawancara di atas, dapat disimpulkan bahwa kelompok siswa berkemampuan tinggi dapat mengoneksikan antar topik dalam matematika. Pada Indikator koneksi matematis dengan ilmu lain yaitu volume kubus dengan bidang fisika seperti debit, kelompok siswa berkemampuan tinggi memberikan jawaban berkorelasi dengan bidang fisika. Soal untuk mengukur indikator nomor 2 adalah soal nomor 2.

Dari jawaban siswa pada soal nomer 2 menunjukkan bahwa siswa sudah bisa menambah informasi untuk soal tidak lengkap tersebut dan memahami hubungan materi matematika dengan konsep bidang lain.

Berikut wawancara HS (Anggota salah satu kelompok) pada soal nomor 2.

$P \quad$ : Bisakah kelompok anda menambah informasi untuk soal tidak lengkap tersebut?

$H S$ : Bisa bu, pada awalnya kelompok kami mendiskusikan kira-kira bangun apa yang cocok dengan luas permukaan bangun yang diketahui dalam soal.

$P \quad$ : Bisakah kelompok anda menguhubungkan panjang sisi bangun tersebut dengan rumus debit?

HS : Bisa bu,

$P \quad$ : Coba tuliskan bagaimana rumusnya?

HS : Debit $=\frac{\text { Volume }}{\text { Waktu }}$.

$P \quad$ : Jadi langkahnya bagaimana?

$H S$ : Dengan mencari volumenya terlebih dahulu

$V=s^{3}$

$V=40^{3}$

$V=64000 \mathrm{~cm}^{3}=64 \mathrm{l}$

$P \quad:$ Setelah itu bagaimana?

$H S$ : Mencari waktu dengan memasukkan volumenya,

$d=\frac{v}{t}$

$2=\frac{64}{t}$

$t=\frac{64}{2}=2$

Jadi waktu yang diperlukan adalah 2 menit

Dari petikan wawancara di atas, diketahui bahwa kelompok tersebut memahami langkah-langkah yang mereka tulis, dan bisa menyebutkan rumus debit, dapat disimpulkan siswa berkemampuan tinggi dapat menghubungkan konsep matematika dengan pelajaran lain.

Pada indikator koneksi matematis dengan kehidupan sehari-hari menghubungkan matematika dengan bidang ekonomi seperti menghitung massa benda untuk mendapatkan nilai ekonomi. Soal untuk mengukur indikator nomer 3 adalah soal nomor 3. Dari jawaban soal nomor 3, kelompok siswa dengan kemampuan tinggi sudah bisa memahami soal dan menambahkan informasi dalam soal tidak lengkap tersebut. Langkah langkah jawaban yang mereka tulis sudah tepat. Ini berarti bahwa siswa dapat menghubungkan konsep Matematika dengan masalah dalam kehidupan sehari-hari.

Berikut wawancara AN (Anggota salah satu kelompok) pada soal nomor 3.

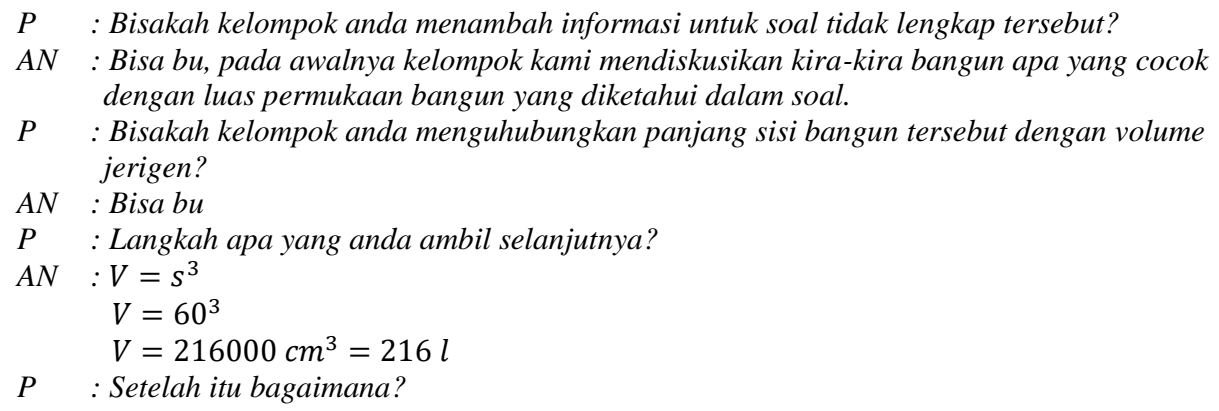




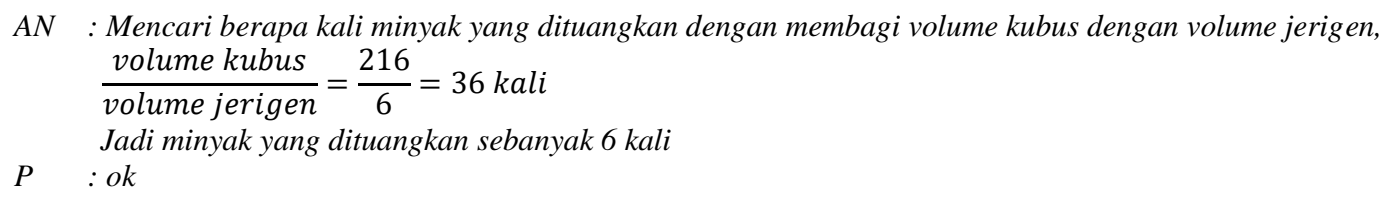

Dari petikan wawancara di atas, diketahui bahwa kelompok tersebut memahami langkah-langkah yang mereka tulis, dapat disimpulkan siswa berkemampuan tinggi dapat menghubungkan konsep matematika dengan kehidupan sehari-hari.

\section{Deskripsi Siswa dengan Kemampuan Matematis Sedang}

Berdasarkan jawaban kelompok diskusi yang termasuk dalam kategori siswa yang memiliki kemampuan matematis sedang, dapat diperoleh kesimpulan bahwa:

Pada Indikator koneksi matematis yang pertama yaitu koneksi antar topik pada materi luas permukaan kubus dengan materi volume kubus dalam menyelesaikan masalah tidak lengkap. Soal untuk mengukur indikator nomer 1 adalah soal nomer 1. Berdasarkan jawaban siswa dapat terlihat bahwa kelompok siswa berkemampuan sedang dapat menambahkan informasi dalam soal tidak lengkap yaitu menggunakan bangun ruang kubus, dan dapat memahami soal dengan baik dengan memahami bahwa yang diketahui adalah luas permukaan kubus, dengan menggunakan rumus luas permukaan kubus maka akan ditemukan panjang rusuk kubus dan memasukkannya pada rumus volume kubus. Berikut petikan wawancara dengan salah satu siswa pada kategori kelompok berkemampuan tinggi. Berikut wawancara FA (Anggota salah satu kelompok) pada soal nomor 1.

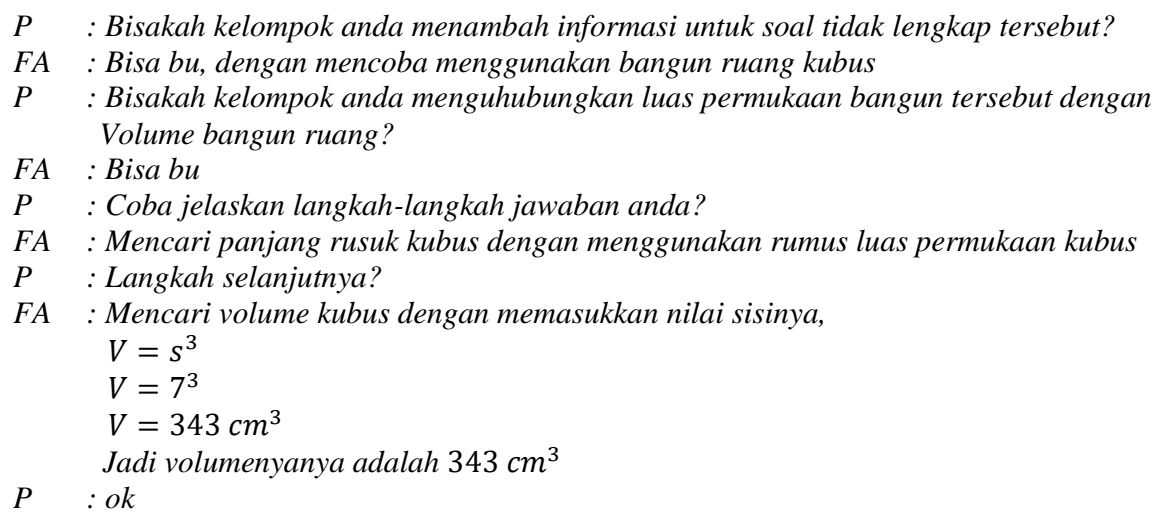

Dari petikan wawancara di atas, dapat disimpulkan bahwa kelompok siswa berkemampuan sedang dapat mengoneksikan antar topik dalam matematika. Indikator koneksi matematis yang kedua yaitu koneksi matematis dengan ilmu lainnya adalah hubungan antara konsep matematika dan mata pelajaran lainnya yaitu volume kubus dengan bidang fisika seperti debit. Soal untuk mengukur indikator nomor 2 adalah soal nomor 2 Berikut jawaban siswa:

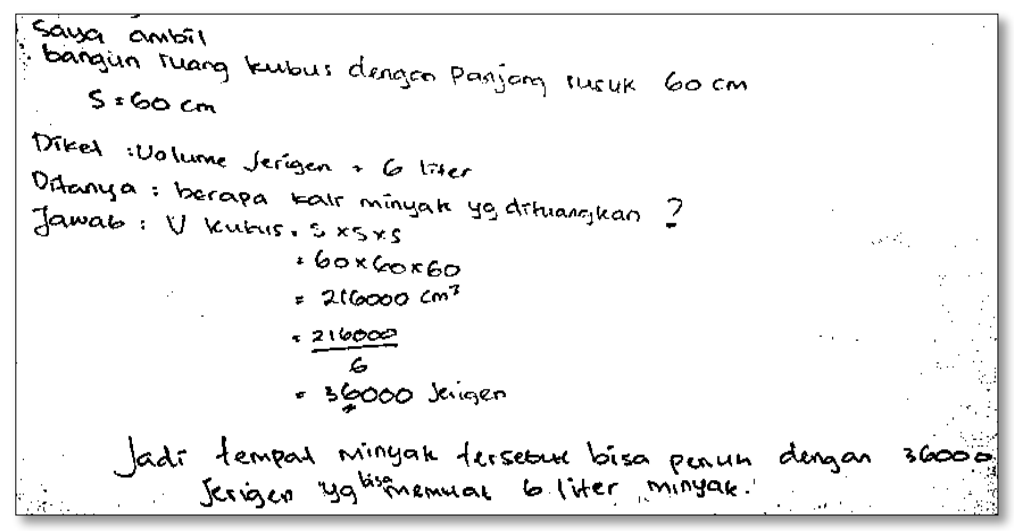

Gambar 3. Hasil Jawaban Kelompok Siswa 
Dari jawaban siswa diatas menunjukkan bahwa siswa sudah benar dalam langkah-langkah menjawab soal, untuk memperkuat hasil jawaban siswa, berikut wawancara MS (Anggota salah satu kelompok) pada soal nomor 2.

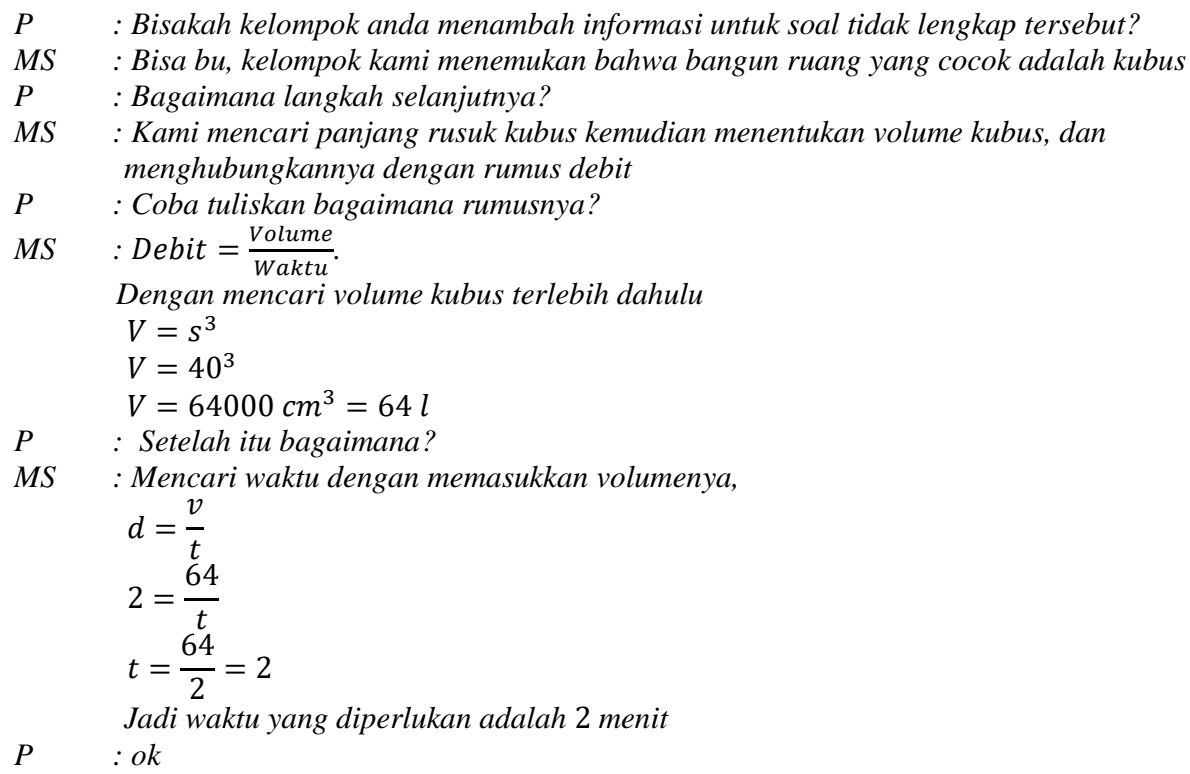

Dari petikan wawancara di atas, kelompok siswa berkemampuan sedang dapat menambahkan informasi dalam soal tidak lengkap dan dapat menghubungkan volume kubus dengan debit sehingga dapat disimpulkan bahwa siswa berkemampuan sedang dapat menghubungkan konsep matematika dengan pelajaran lain.

Selanjutnya Indikator koneksi matematis yang ketiga adalah koneksi matematis dengan kehidupan sehari-hari dengan menghubungkan antara konsep matematika dan kehidupan sehari-hari pada materi matematika dengan bidang ekonomi. Soal untuk mengukur indikator nomor 3 adalah soal nomor 3.

Berdasarkan jawaban soal nomor 3, kelompok siswa dengan kemampuan sedang sudah bisa memahami soal dan melengkapi soal yang tidak lengkap tersebut. Tetapi masih salah pada langkah langkah jawaban yang mereka tulis, sehingga jawaban mereka masih belum tepat. Berikut wawancara IR (Anggota salah satu kelompok) pada soal nomor 3.

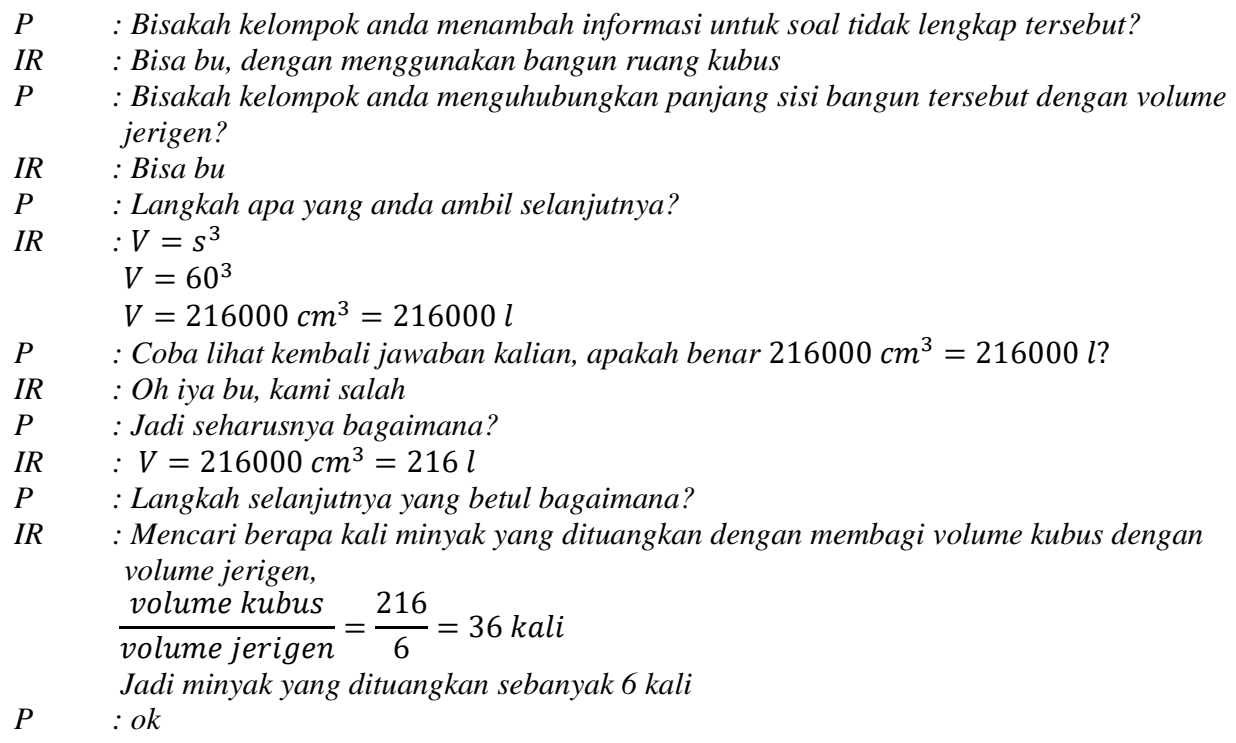

Dari petikan wawancara di atas, diketahui bahwa kelompok tersebut dapat menambahkan informasi dalam soal tidak lengkap, sudah bisa memahami soal tapi belum benar dalam langkah-langkah penyelesaiannya, dapat disimpulkan siswa berkemampuan sedang belum mampu menghubungkan konsep matematika dengan kehidupan sehari-hari. 


\section{Deskripsi Siswa dengan Kemampuan Matematis Rendah}

Berdasarkan jawaban kelompok diskusi yang termasuk dalam kategori siswa yang memiliki kemampuan matematis rendah, dapat diperoleh kesimpulan bahwa:

Pada indikator koneksi matematis antar topik matematika yaitu satu pertanyaan masalah tidak lengkap yang dihubungkan dengan koneksi matematis. Soal untuk mengukur indikator nomor 1 adalah soal nomor 1 . Berdasarkan hasil jawaban kelompok siswa berkemampuan rendah, siswa mampu menambahkan informasi dalam soal tidak lengkap, dan siswa dapat memahami hubungan antara luas permukaan kubus dengan volume kubus. Berikut petikan wawancara dengan salah satu siswa pada kategori kelompok berkemampuan tinggi.

Berikut wawancara GR (Anggota salah satu kelompok) pada soal nomor 1.

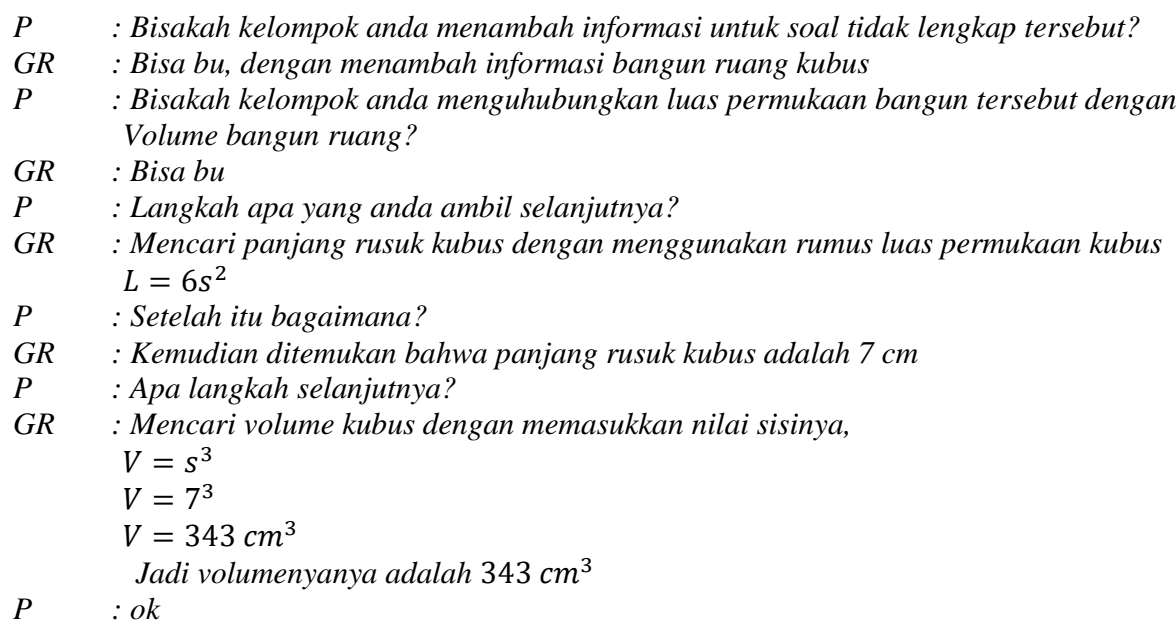

Dari petikan wawancara di atas, dapat disimpulkan bahwa kelompok siswa berkemampuan sedang dapat mengoneksikan antar topik dalam matematika.

Pada Indikator keterkaitan antara konsep matematika dengan ilmu lainnya adalah konsep matematika dengan bidang fisika. Ini adalah jawaban siswa yang benar. Soal untuk mengukur indikator nomer 2 adalah soal nomer 2.

Berdasarkan hasil jawaban siswa menunjukkan bahwa siswa sudah bisa menambah informasi untuk soal tidak lengkap tersebut tetapi tidak memahami konsep bidang lain. $\mathrm{D}=\mathrm{L} / \mathrm{S}$ (debit = liter $\mathrm{x}$ waktu). Data ini, yang didukung oleh wawancara siswa yang tidak bisa menjawab lagi, mengatakan bahwa kesulitan dalam menentukan rumus debit.

Berikut wawancara RS (Anggota salah satu kelompok) Pada soal nomor 2.

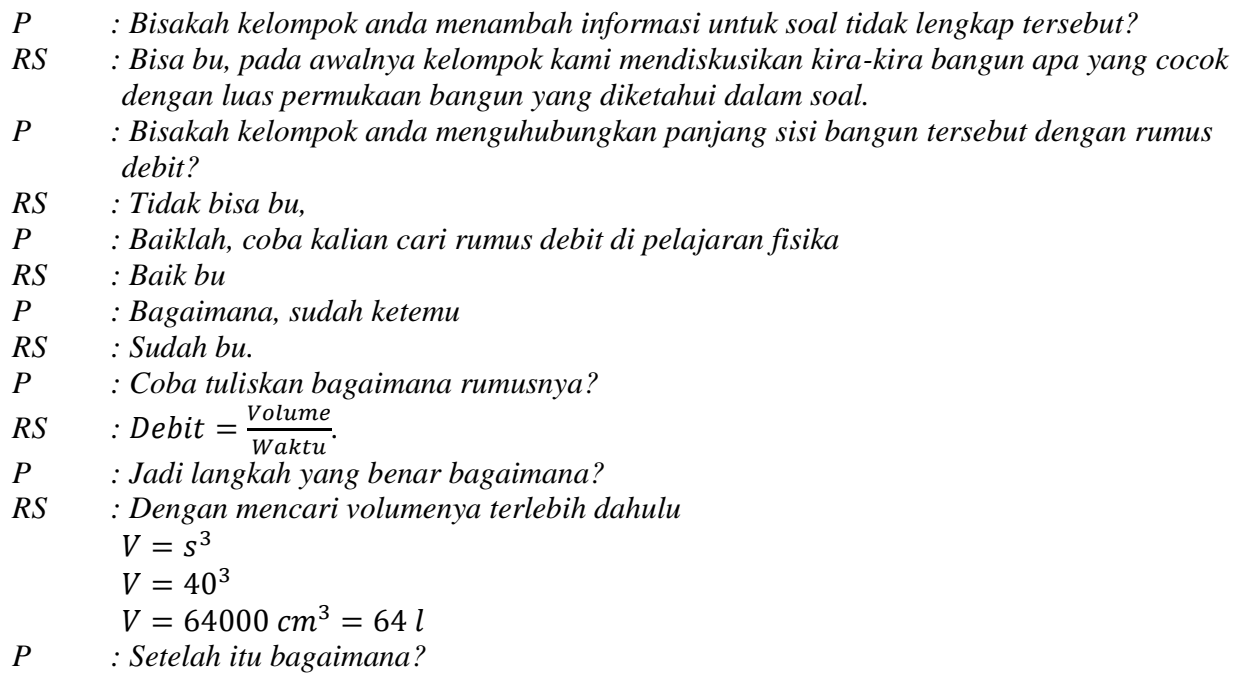


$R S$

$$
\begin{aligned}
& \begin{array}{l}
\text { Mencari waktu dengan memasukkan volumenya, } \\
\begin{array}{l}
d=\frac{v}{t} \\
2
\end{array}=\frac{64}{t}
\end{array} \\
& t=\frac{64}{2}=2 \\
& \text { Jadi waktu yang diperlukan adalah } 2 \text { menit } \\
& \text { ok }
\end{aligned}
$$

$P$

Dari petikan wawancara di atas, diketahui bahwa kelompok tersebut memahami langkah-langkah yang mereka tulis, namun tidak bisa menyebutkan rumus debit, kesalahan ini membuat langkah-langkah lainnya juga salah, dapat dikatakan bahwa kelompok siswa berkemampuan rendah belum mampu mengoneksikan matematika dengan mata pelajaran lain.

Pada indikator hubungan antara konsep matematika dan kehidupan sehari-hari adalah konsep matematika yang berhubungan dengan bidang ekonomi. Soal untuk mengukur indikator nomor 2 adalah soal nomor 2. Berikut Jawaban dari siswa:

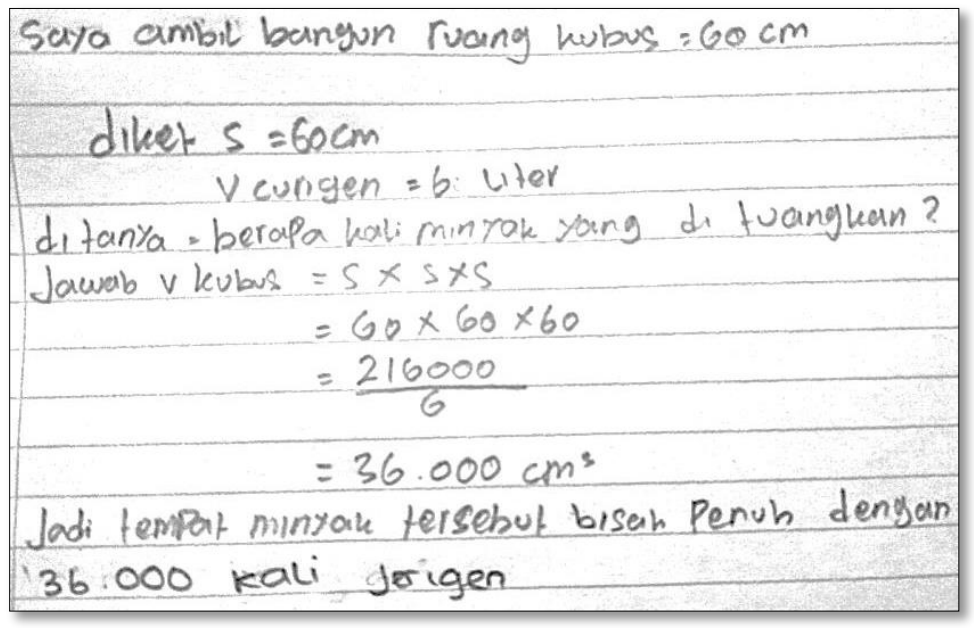

\section{Gambar 4. Hasil Jawaban Kelompok Siswa}

Dari jawaban terlihat bahwa kelompok siswa berkemampuan rendah belum bisa memahami pertanyaan dengan baik. Pada pertanyaan itu, diketahui bahwa sebuah tempat minyak berbentuk bangun ruang mempunyai panjang rusuk $60 \mathrm{~cm}$, tempat minyak akan diisi penuh minyak dengan menggunakan jerigen yang dapat memuat minyak 6 liter. Tetapi langkah langkah jawaban yang mereka tulis masih belum tepat. Ini berarti bahwa siswa tidak dapat menghubungkan konsep matematika dengan masalah dalam kehidupan sehari-hari. Berikut wawancara AB (Anggota salah satu kelompok) pada soal nomer 3;

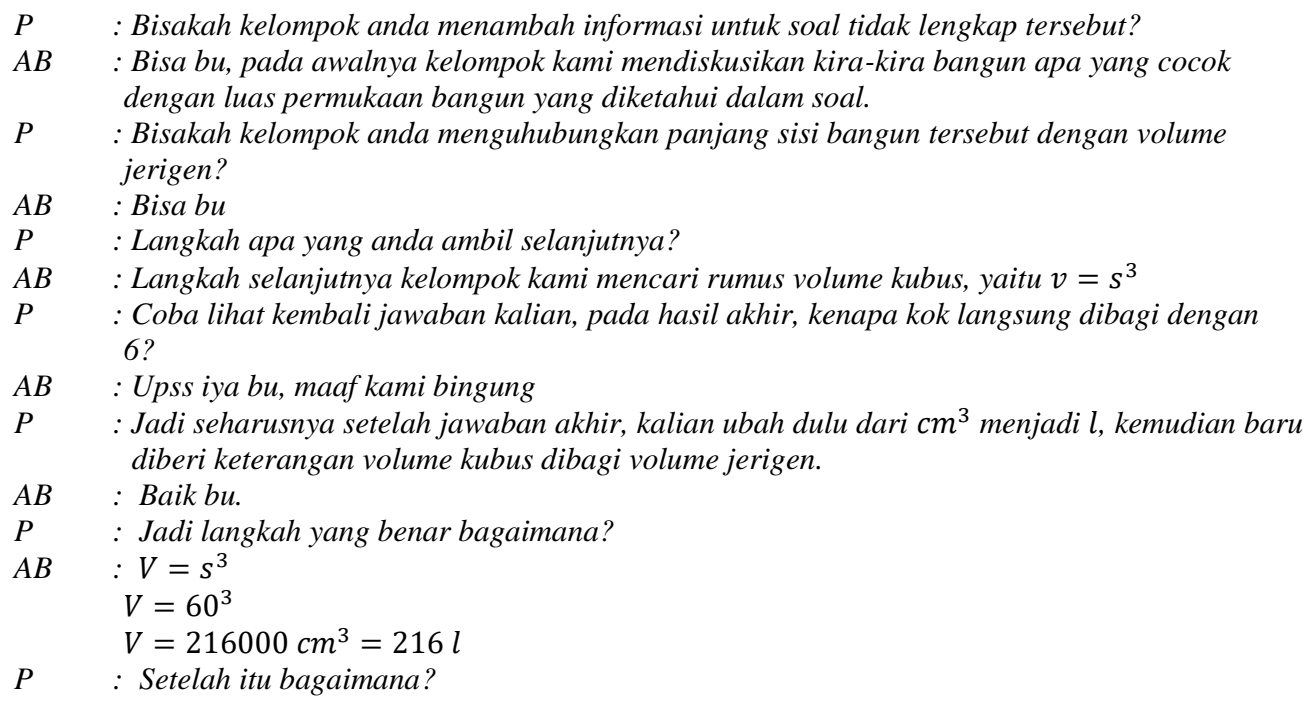




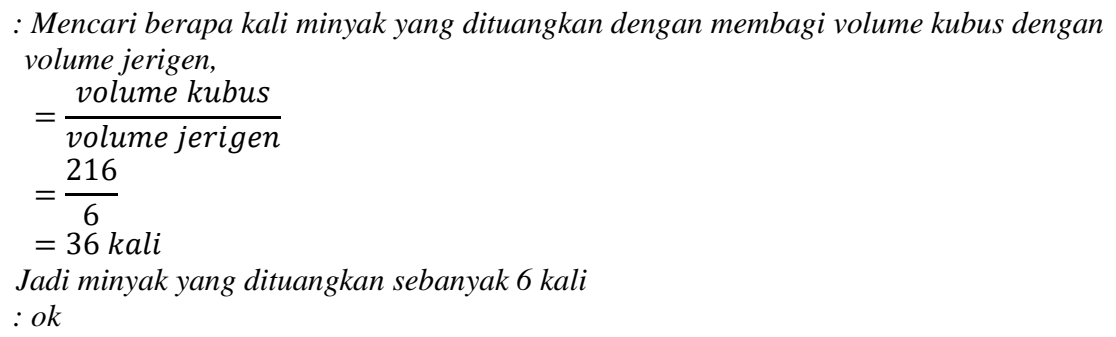

Dari petikan wawancara di atas, diketahui bahwa kelompok siswa berkemampuan rendah memahami langkah-langkah yang mereka tulis, namun terdapat kesalahan pada langkah rumus volume kubus, kesalahan ini membuat langkah-langkah lainnya juga salah, dapat dikatakan bahwa kelompok tersebut belum mampu mengoneksikan matematika dengan kehidupan sehari-hari

\section{PEMBAHASAN}

Siswa dengan kemampuan matematis tinggi pada indikator koneksi antar topik matematika, telah berhasil menambahkan informasi pada soal tidak lengkap dan telah menghubungkan materi luas permukaan kubus dengan volume kubus, sehingga siswa dengan kemampuan tinggi telah melakukan koneksi antar topik matematika. Pada indikator selanjutnya yaitu indikator koneksi matematis dengan ilmu lain, siswa dengan kemampuan tinggi mampu menambah informasi pada soal tidak lengkap dengan menjelaskan bahwa bangun tersebut adalah kubus, dan juga mampu menghubungkan materi matematika dengan materi ilmu lai yaitu fisika, sehingga mereka telah melakukan koneksi matematis dengan ilmu lain. Kemudian pada indikator koneksi matematis dengan kehidupan sehari-hari, siswa berkemampuan tinggi juga telah menambah informasi pada soal, sehinggal bisa menyelesaikan soal tersebut dengan baik, mereka juga telah menghubungkan materi matematika dengan kehidupan sehari-hari, sehingga siswa berkemampuan tinggi telah melakukan koneksi matematis dengan kehidupan sehari-hari. hal ini sejalan dengan pendapat Lestari, Rohaeti, \& Purwasih (2018) yang mengemukakan bahwa kemampuan koneksi matematis berbeda-beda, hal ini dikarenakan salah satunya yaitu pemahaman sebelumnya yang mereka miliki mempunya tingkat yang berbeda terhadap suatu konsep yang digunakan untuk menyelesaikan masalah. Sehingga apabila sebelumnya siswa tersebut memiliki kemampuan matematis yang tinggi besar kemungkinannya akan mempunyai koneksi matematis yang tinggi pula yang artinya mampu melakukan koneksi matematis pada semua indikator.

Siswa dengan kemampuan matematis sedang mampu menyelesaikan soal tidak lengkap dengan baik dengan menambah informasi pada soal, mereka juga mampu menghubungkan rumus luas permukaan kubus dengan volum kubus, sehingga mereka telah melakukan koneksi matematis antar topik, pada indikator koneksi matematis dengan ilmu lain, siswa berkemampuan sedang mampu melengkapi soal tidak lengkap dan mampu menghubungkan materi ilmu lain yaitu ilmu fisika yaitu debit dengan materi volume kubus sehingga siswa berkemampuan sedang mampu melakukan koneksi matematis dengan ilmu lain. Kemudian pada indikator koneksi matematis dengan kehidupan sehari-hari, siswa berkemampuan sedang telah melengkapi informasi dalam soal, tetapi belum tepat dalam menghubungkan konsep matematika dengan masalah ekonomi dalam kehidupan seharihari, sehingga mereka tidak melakukan koneksi matematis dengan kehidupan sehari-hari. Sesuai dengan pendapat Ni'mah, Setiawani, \& Oktavianingtyas (2017) bahwa sebagian besar koneksi matematis siswa masih tergolong sedang.

Siswa dengan kemampuan matematis rendah pada indikator pertama yaitu koneksi antar topik matematika, mampu melengkapi informasi pada soal dan mampu menghubungkan materi luas permukaan kubus dan volume kubus sehingga mereka telah melakukan koneksi antar topik matematika. Selanjutnya, indikator yang kedua yaitu koneksi matematis dengan ilmu lain, siswa berkemampuan rendah sudah berhasil menambah informasi pada soal, tetapi belum mampu menghubungkan rumus fisika dengan rumus volume kubus sehingga siswa berkemampuan rendah tidak melakukan koneksi matematis dengan ilmu lain. Kemudian indikator yang ketiga yaitu koneksi matematis dengan kehidupan sehari-hari, siswa berkemampuan rendah telah mampu menambah informasi pada soal, tetapi tidak dapat menghubungkan materi matematika dengan kejadian pada kehidupan sehari-hari yaitu pada masalah ekonomi sehingga siswa berkemampuan rendah tidak melakukan koneksi matematis dengan kehidupan sehari-hari. Hal ini sesuai dengan pendapat Ainurrizqiyah dkk. (2015) bahwa siswa dengan kemampuan rendah tidak dapat menyelesaikan soal tes koneksi dengan baik dikarenakan kesalahan konsep yang dilakukan ketika menjawab soal sehingga tidak dapat menghubungkan gagasan yang satu dengan gagasan lainnya.

\section{SIMPULAN}

Berdasarkan hasil penelitian mengenai analisis kemampuan koneksi matematis siswa pada siswa kelas VIII MTs. Sultan Agung Kalipare, maka dapat ditarik beberapa kesimpulan sebagai berikut.

Pertama, siswa berkemampuan tinggi menguasai ketiga indikator koneksi matematis siswa dengan baik, yaitu koneksi matematis antar topik matematika, koneksi matematis dengan mata pelajaran lain, dan koneksi matematis dengan kehidupan sehari-hari. 
Kedua, siswa berkemampuan sedang yaitu siswa dapat menguasai indikator pertama karena siswa dapat mengoneksikan antar topik matematika. Siswa juga dapat menguasai indikator kedua yaitu koneksi matematis dengan mata pelajaran lain. Tetapi pada indikator ketiga yaitu penerapan dalam kehidupan sehari-hari, siswa belum dapat menerapkannya. Siswa hanya menghafal rumus, tetapi tidak memahaminya sehingga siswa berkemampuan koneksi matematis sedang hanya menguasai dua indikator koneksi matematis.

Ketiga, siswa berkemampuan rendah. Siswa tidak dapat memahami koneksi matematis dengan mata pelajaran lain. Siswa juga tidak dapat mengenali dan menerapkan matematika dalam konteks di luar matematika yaitu penerapan dalam kehidupan sehari-hari. Oleh karena itu, siswa berkemampuan koneksi matematis rendah hanya menguasai satu indikator koneksi matematis.

Berdasarkan hasil penelitian, maka peneliti mengemukakan saran bahwa hendaknya menfasilitasi kegiatan pembelajaran dengan membiasakan siswa menyelesaikan permasalahan koneksi matematis dengan banyak mengerjakan latihan soal matematika khususnya bangun ruang sisi datar agar dapat meningkatkan kemampuan menjawab soal dengan cara yang beragam sehingga kemampuan koneksi matematis siswa meningkat.

\section{DAFTAR RUJUKAN}

Abdillah, \& Mastuti, A. G. (2018). Munculnya Kreativitas Siswa Akibat Ill Structured Mathematical Problem. Jurnal Matematika dan Pembelajaran, 6(1), 48-59.

Adamura, F. (2017). Efektivitas Pembelajaran Diskusi Kelas Berbasis Diskusi Kelompok Intuitif pada Matakuliah Sistem Geometri. Jurnal Math Educator Nusantara, 03(01), 53-57.

Ainurrizqiyah, Z., Mulyono, \& Sutarto, H. (2015). Keefektifan Model PjBL dengan Tugas Creative Mind-Map untuk Meningkatkan Koneksi Matematik Siswa. Journal of Mathematics Education, 4(2), 172-179.

Aziziy, Y. N., Sulhadi, \& Hartono. (2015). Penerapan Model Ill Structured Cooperative Problem Solving (ICPS) untuk Meningkatkan Metakognisi Siswa. Journal of Innovative Science Education, 4(2), 8-14.

Fathani, A. H. (2009). Hakekat dan Logika. Ar-Ruzz Media.

Haji, S., Abdullah, M. I., Maizora, S., \& Yumiati, Y. (2017). Developing Students' Ability of Mathematical Connection Through Using Outdoor Mathematics Learning. Infinity Journal, 6(1), 11. https://doi.org/10.22460/infinity.v6i1.234

Hasanah, Abdussamad, \& Rosnita. (2013). Pengaruh Metode Diskusi Kelompok terhadap Aktivitas Pembelajaran Matematika di Kelas III SDN 19 Mempawah Hilir.

Lestari, R. S., Rohaeti, E. E., \& Purwasih, R. (2018). Profil Kemampuan Koneksi Matematis Siswa SMP Dalam Menyelesaikan Soal Bangun Ruang Sisi Datar Ditinjau dari Kemampuan Dasar. Jurnal Ilmiah Pendidikan Matematika, 3(1), 51-58.

McGregor, D. (2014). Does Inquiry Based Learning Affect Students' Beliefs and Attitudes Towards Mathematics? The Mathematics Education Research Group of Australasia, 453-460.

Ni'mah, A. F., Setiawani, S., \& Oktavianingtyas, E. (2017). Analisis Kemampuan Koneksi Matematika Siswa Kelas IX A MTs Negeri 1 Jember Sub Pokok Bahasan Kubus dan Balok. Jurnal Edukasi, IV(1), 30-33.

Pono, N., \& Lutfi, M. (2012). Pengaruh Pembelajaran Menggunakan Metode Diskusi Kelompok terhadap Prestasi Belajar Siswa pada Pokok Bahasan Geometri Dimensi Tiga di MAN Kalimukti Kec. Pabedilan Kab. Cirebon. EduMa: Mathematics Education Learning and Teaching, 1(2), 63-72.

Redhana, I. W., Sudiatmika, A. A. I. A. R., \& Artawan, I. K. (2009). Pengembangan Perangkat Pembelajaran Berbasis Masalah dan Pertanyaan Socratik untuk Meningkatkan Keterampilan Berpikir Kritis Siswa SMP. Jurnal Pendidikan dan Pengajaran, 151-159.

Rohendi, D. (2012). Developing E-Learning Based on Animation Content for Improving Mathematical Connection Abilities in High School Students. 9(4), 5.

Saminanto, K. (2015). Analysis of Mathematical Connection Ability in Linear Equation with ONE Variable Based on Connectivity Theory. International Journal of Education and Research 2, 4(3), 259-270.

Vinsensia, D. (2016). Upaya Peningkatan Hasil Belajar dengan Teknik Diskusi Kelompok pada Pokok Bahasan Bilangan Bulat dan Pola Bilangan oleh Siswa SMP Negeri 1 Tanjung Pura Kab. Langkat. Junal Manajemen dan Informatika Komputer Pelita Nusantara, 19(1), 1-8. 